$\mathbf{K}$

\section{K.U. LEUVEN FACULTY OF SCIENCE}

Geel Huis, Kasteelpark Arenberg 11 - bus 2100, 3001 Leuven (Heverlee)

Tel: +3216321401

Email: info.wet@kuleuven.be

\section{Science@Leuven Scholarships}

Subjects: Astronomy and astrophysics, biology, chemistry, geography, mathematics, physics, statistics, geology, biophysics, biochemistry and biotechnology.

Purpose: The Science@Leuven Scholarships are for motivated and talented international students who are interested in participating in an international master programme of the Faculty of Science of the K.U. Leuven.

Type: Scholarship

Value: $€ 10.000$

Length of Study: 1 year

Frequency: Annual

Study Establishment: Katholieke Universiteit Leuven in Belgium No. of awards offered: Not specified

Application Procedure: Applicants have to apply for the master's programme of their choice through the application form of the KU

Leuven. The applicants should note in the application form that they want to apply for the Science@Leuven Scholarship. After completing the application form on the official KU Leuven application page, applicants need to register on the website of the scholarship. Closing Date: February 15th

Additional Information: For more details, please check official scholarship website: http://wet.kuleuven.be/english/ scienceatleuvenscholarship.

\section{KAISER FAMILY FOUNDATION (KFF)}

2400 Sand Hill Road, Menlo Park, CA, 94025, United States of America

Tel: (1) 6508549400,2349220

Fax: (1) 650854 4800/7465

Email: pduckham@kff.org

Website: www.kff.org

Kaiser Family Foundation (KFF) is a non-profit, private operating foundation that focuses on the major health care issues facing the nation. KFF is an independent voice and source of facts and analysis for policymakers, the media, the health care community and the general public.

\section{The Kaiser Media Fellowships in Health}

\section{Subjects: Journalism.}

Purpose: To help journalists and commentators do the best possible job of keeping the public informed about health issues at this critical time in the evolution of our health care system.

Eligibility: Open to any journalist, editor or producer specializing in health reporting. The applicants must be citizens of the US or must work for an accredited U.S. media organization.

Level of Study: Professional development

Type: Fellowship

Value: Up to 10 stipends will be awarded based on the length of the fellowship - up to US\$50,000 for a 9-month fellowship. The programme also covers travel costs and computer equipment based on the needs of the project

Length of Study: 9 months

Country of Study: United States of America

No. of awards offered: 10

Application Procedure: There is no application form. For details of the procedure see the website.

Closing Date: March 3rd

Funding: Foundation

Additional Information: There is no age restriction, but typically fellows must be in the early to mid-career range, with at least 5 years experience as a journalist. Please see the website for further details http://kff.org/the-kaiser-media-fellowships-in-health-reporting/.

\section{KATHOLIEKE UNIVERSITEIT LEUVEN}

Oude Markt 13, Bus 5005, Leuven, 3000, Belgium

Tel: (32) 16324010

Fax: (32) 16324014

Email: csb@dir.kuleuven.be, info@kuleuven.be

Website: www.kuleuven.be

Situated at the heart of Western Europe, Katholieke Universiteit Leuven has been a centre of learning for almost 6 centuries. Founded in 1425 , by Pope Martin V, Katholieke Universiteit Leuven bears the double honour of being the oldest extant Catholic university in the world and the oldest university in the Low Countries.

\section{Special Doctoral Students Grants for Advanced K.U. Leuven Doctoral Students}

Subjects: All subjects.

Purpose: To encourage fundamental and applied research in all academic disciplines.

Eligibility: Open to doctoral students from non-EEA countries who wish to complete their project at Katholieke.

Level of Study: Doctorate

Type: Scholarships

Value: A part-time salary will be paid for half-time contracts

Length of Study: 12 months

Frequency: Annual

No. of awards offered: 3

Closing Date: January 31st

Contributor: Katholieke Universiteit Leuven

Additional Information: Please see the website for further details www.kuleuven.be/research/funding/bof/personal/.

\section{KAY KENDALL LEUKAEMIA FUND}

\author{
The Peak, Third Floor, 5 Wilton Road, London, SW1V 1AP, \\ England \\ Tel: (44) 02074100330 \\ Fax: (44) 02074100332 \\ Email: info@kklf.org.uk \\ Website: www.kklf.org.uk \\ Contact: Ms Helen McLeod, Fund Executive
}

The Kay Kendall Leukaemia Fund awards grants for research on aspects of leukaemia and for relevant studies on related haematological malignancies. Applications are welcomed for first class research on innovative proposals via the fellowship or project grant routes. Please see website for full details.

\section{Kay Kendall Leukaemia Fund Research Fellowship \\ Subjects: Aspects of leukaemia or relevant studies on related haematological malignancies.}

Purpose: Research Fellowships on aspects of Leukaemia and related haematological malignancies.

Eligibility: Open to applicants of any nationality intending to work mainly in the United Kingdom. Applicants must hold a recognized higher degree, but need not be medically qualified.

Level of Study: Postdoctorate

Type: Fellowship

Value: Salary and laboratory expenses

Length of Study: Junior (3 years), Intermediate (4 years)

Frequency: Annual

Country of Study: United Kingdom

No. of awards offered: $2-3$

Application Procedure: Applicants must submit a research proposal form and details of support from the intended United Kingdom institution.

Closing Date: Please see website for details

Funding: Trusts

No. of awards given last year: Junior (2), Intermediate (1)

Additional Information: $£ 17,000$ per year to contribute to the cost of laboratory consumables and a further amount up to $£ 1,000$ per year to cover travel costs to meetings (for junior fellowship). 


\section{KEELE UNIVERSITY}

Keele, Staffordshire, ST5 5BG, United Kingdom Tel: (44) 01782732000

Email: admissions.ukeu@keele.ac.uk

Website: www.keele.ac.uk

Keele University is renowned for its exciting approach to higher education, beautiful campus, strong community spirit and excellent student life. It was the first new United Kingdom university of the 20th century, established with degree giving powers in 1949 as the University College of North Staffordshire. University status, as the University of Keele, followed in 1962.

\section{Postgraduate Scholarship for International Student at Keele University in UK}

Subjects: Scholarships are provided for any one course offered by Keele University in UK.

Purpose: The scholarships are available for pursuing postgraduate degree level at Keele University in UK.

Eligibility: To apply for the KIS Scholarship, applicants must have applied to Keele and been offered a place to study there. They must then complete a separate application form. Applications must have been received and processed before the start of the academic year for which the application is made. KIS Scholarships cannot be awarded to students who have already started their degree at Keele.

Level of Study: Postgraduate

Type: Scholarship

Value: Scholarship is awarded towards the cost of applicant's

Master's tuition fees

Country of Study: United Kingdom

Application Procedure: The mode of applying is by post.

Closing Date: August 28th

Contributor: Keele University in UK

Additional Information: The students from all non-EU countries can apply for the scholarships.

\section{KENNAN INSTITUTE}

Woodrow Wilson International Center for Scholars, One Woodrow Wilson Plaza, 1300 Pennsylvania Avenue North West, Washington, DC, 20004 3027, United States of America Tel: (1) 2026914100 Fax: (1) 2026914247

Email: kennan@wilsoncenter.org

Website: www.wilsoncenter.org

Contact: Scholar Programs

The Kennan Institute for Advanced Russian Studies sponsors advanced research on the successor states to the USSR and encourages Eurasian studies with its public lecture and publication programmes, maintaining contact with scholars and research centres abroad. The Institute seeks to function as a forum where the scholarly community can interact with public policymakers.

\section{Fulbright-Kennan Institute Research Scholarships}

Subjects: Social sciences and humanities. Research proposals examining topics in Eurasian studies are eligible, with those topics relating to regional Russia, the NIS and contemporary issues especially welcome.

Purpose: To offer support to junior scholars studying the former Soviet Union, allowing them time and resources in the Washington DC area to work on their first published work or to continue their research. Eligibility: Open to scholars and researchers who have at least 2 years postdoctoral (post-Kandidat) academic and research experience. Applicants must be eligible to obtain a J-1 exchange visitor visa. Level of Study: Postdoctorate

Type: Scholarship

Value: US $\$ 3,300$ per month plus research facilities, computer support and some research assistance

Length of Study: 6 months

Frequency: Dependent on funds available

Study Establishment: The Kennan Institute

Country of Study: United States of America

No. of awards offered: 5
Application Procedure: Applicants must complete an application form. The application must include a project proposal, publications list bibliography, biographical data and three letters of recommendation specifically in support of the research to be conducted at the Institute. Applications received by fax or email will not be accepted.

Closing Date: July 15th (for Russian applicants) and October 15th (for Ukrainian applicants)

Funding: Government

No. of awards given last year: 5

No. of applicants last year: 14

Additional Information: Eligible to nationals of Russia and Ukraine, specifically. Please see the website for further details www.wilsoncenter.org/opportunity/fulbright-kennan-institute-researchscholarships.

\section{Title VIII-Supported Short-Term Grant}

Subjects: Eurasian studies in the social sciences and humanities. Social sciences and humanities focusing on the former Soviet Union excluding the Baltic States.

Purpose: To support U.S. citizens whose research in the social sciences or humanities focuses on the former Soviet Union (excluding the Baltic States), and who demonstrate a particular need to utilize the library, archival, and other specialized resources of the Washington, DC area.

Eligibility: Open to academic participants with a doctoral degree or those who have nearly completed their dissertations. For nonacademic participants, an equivalent level of professional development is required. Applicants must be U.S. citizens.

Level of Study: Doctorate, Postdoctorate, Postgraduate, Predoctorate, Professional development, Research

Type: Scholarship

Value: $\$ 3,200$ for 31 days ( $\$ 103.22$ per day)

Length of Study: Up to 31 days

Frequency: Dependent on funds available

Study Establishment: The Kennan Institute

Country of Study: United States of America

No. of awards offered: 4 are available to citizens of the USA

Application Procedure: Applicants must submit a concise description of their research project of $700-800$ words, a curriculum vitae, a statement on preferred dates of residence in Washington DC and two letters of recommendation specifically in support of the research to be conducted at the institute. No application form is required for shortterm grants.

Closing Date: February 15th and July 15th

Funding: Government

No. of awards given last year: 5

No. of applicants last year: 97

Additional Information: For more information, please email kennan@wilsoncenter.org. Please see the website for further details www.wilsoncenter.org/opportunity/kennan-institute-short-term-grant.

\section{Title VIII-Supported Summer Research Grant}

Subjects: Eurasian studies in the social sciences and humanities. Purpose: To support U.S. citizens whose research in the social sciences or humanities focuses on the former Soviet Union, and who demonstrate a particular need to use the resources of the Washington DC area.

Eligibility: Open to academic participants with a doctoral degree or those who have nearly completed their dissertation. For non-academic participants, an equivalent level of professional development is required. Applicants must be U.S. citizens.

Level of Study: Doctorate, Postdoctorate, Research, Postgraduate, Predoctorate, Professional development

Type: Scholarship

Value: $\$ 6,400$. The Kennan Institute provides a work space and research assistant for each Summer Scholar. Travel and accommodation expenses are not directly covered by this grant

Length of Study: Up to 62 days

Frequency: Dependent on funds available

Study Establishment: The Kennan Institute

Country of Study: United States of America

No. of awards offered: 2 per summer

Application Procedure: Applicants must submit a concise description of their research project of $700-800$ words, a curriculum vitae, a statement of preferred dates of residence in Washington, DC, and two 
letters of recommendation specifically in support of the research proposal. No application form required.

Closing Date: January 15th

Funding: Government

No. of awards given last year: 2

No. of applicants last year: 25

Additional Information: Please email kennan@wilsoncenter.org or see our website with further details www.wilsoncenter.org/opportunity/ kennan-institute-summer-research-scholarships.

\section{KENNEDY MEMORIAL TRUST}

\author{
3 Birdcage Walk, Westminster, London, SW1H 9JJ, England \\ Tel: (44) 02072221151 \\ Fax: (44) 02072227189 \\ Email: annie@kennedytrust.org.uk \\ Website: www.kennedytrust.org.uk \\ Contact: Ms Annie Thomas, Secretary
}

As part of the British national memorial to President Kennedy, the Kennedy Memorial Trust awards scholarships to British postgraduate students for study at Harvard University or the Massachusetts Institute of Technology. The awards are offered annually following a national competition and cover tuition costs and a stipend to meet living expenses.

\section{Kennedy Scholarship for British Citizens}

Subjects: The scholarship is provided to enable British citizens, educated in the United Kingdom, to undertake graduate study across a wide variety of disciplines Harvard University and the Massachusetts Institute of Technology in the United States of America.

Purpose: The Kennedy Scholarship is an academic award for study. It can be used to fund a wide variety of programmes at MIT and across all the graduate schools within Harvard - from PhD to LLM, from MPH to MArch. It can also fund a Special Studentship for those wanting a general programme of non-degree study.

Eligibility: British citizens, ordinarily resident in the United Kingdom and wholly or mainly educated in the United Kingdom.

Level of Study: Doctorate, MBA, Postgraduate, Professional

development

Type: Scholarship

Value: Scholars will receive a stipend of at least $\$ 25,000$ to cover living costs, any special equipment needed, and some travel within the United States. Scholars are expected to spend part of their summer vacation in the United States after the end of the academic year and may apply for an additional grant of $\$ 2,500$ to pay for vacation travel. A substantial contribution toward one outward and return air fare for transatlantic travel will be paid for by the Trust, and tuition fees will be paid direct to the institution concerned

Length of Study: Normally 1 year

Frequency: Annual

Study Establishment: Harvard University and MIT

Country of Study: United States of America

Application Procedure: Applications are to be made online and comprise a form for educational history plus a 1,000 word personal statement.

Closing Date: Late October

Funding: Private

Contributor: Charitable donations

No. of awards given last year: 7

No. of applicants last year: 250

Additional Information: Full information on the website.

\section{Kennedy Scholarships}

Subjects: All fields of arts, science, social science and political studies.

Purpose: To enable students to undertake Graduate study in the United States of America at two particular universities.

Eligibility: Open to resident citizens of the United Kingdom who have been wholly or mainly educated in the United Kingdom. Applicants must have graduated by the start of tenure; they must have completed a first degree not earlier than 2013 for awards tenable in 2018-2019 and have spent 2 of the 7 academic years prior to September 1 st at a UK university in the year of award.

Level of Study: Doctorate, Graduate, MBA, Postgraduate
Type: Scholarship

Value: At least US\$26,000 to cover support costs, special equipment and some travel in the United States of America, plus tuition fees and a contribution towards travelling expenses to and from the United States of America. Students applying for 2 year masters or PhD programmes will normally secure the necessary funding for second or subsequent years within their institution

Length of Study: 1 year

Frequency: Annual

Study Establishment: Harvard University and the Massachusetts Institute of Technology (MIT), Cambridge, MA

Country of Study: United States of America

No. of awards offered: 10

Application Procedure: Applications are made online at www. kennedytrust.org.uk and comprise an online form, a statement of purpose and two references which are to be submitted online before the closing data.

Closing Date: Usually late October. See webiste for updates

Funding: Private

Contributor: Public donation

No. of awards given last year: 7

No. of applicants last year: 250

Additional Information: Scholars are not required to study for a degree in the United States of America, but are encouraged to do so if they are eligible and able to complete the requirements for it. Please see the website for further details www.kennedytrust.org.uk/display. aspx id $=1173$ \&pid $=243$.

\section{KIDNEY HEALTH AUSTRALIA}

Level 1, 25 North Terrace, GPO Box 9993, Adelaide, SA, 5001, Australia

Tel: (61) 0883347555

Fax: (61) 0883347545

Email: research@kidney.org.au

Website: www.kidney.org.au

Contact: Medical Director's Office

Founded in 1968, the Australian Kidney Foundation's mission is to be recognized as the leading non-profit national organization providing funding for, and taking the initiative in, the prevention of kidney and urinary tract diseases.

Australian Kidney Foundation Biomedical Scholarships

Subjects: Medical and scientific kidney and urology-related research. Purpose: To provide scholarships for individuals wishing to study full-time for the research degrees.

Eligibility: Open to Australian applicants who are graduates, or proposing to graduate in the current academic year. Part-time students are not eligible.

Level of Study: Doctorate, Postgraduate

Type: Scholarship

Value: Australian $\$ 24,000$ for science and $\$ 35,000$ for medical

Length of Study: 2 or 3 years

Frequency: Annual

No. of awards offered: Varies

Closing Date: August 31st

Contributor: Kidney Health Australia

For further information contact:

Kidney Health Australia, GPO Box 9993, Adelaide SA, 5001, Australia Contact: The Medical Director

\section{Australian Kidney Foundation Medical Research Grants and Scholarships}

Subjects: The functions and disease of the kidney, urinary tract and related organs.

Purpose: To support medical research.

Eligibility: Open to Australian citizens who are graduates of

Australian medical schools or overseas graduates who are eligible for Australian citizenship and for registration as medical practitioners in Australia.

Level of Study: Postgraduate, Doctorate

Type: Scholarship

Value: Please contact the organization 
Length of Study: Up to 3 years

Frequency: Annual

Study Establishment: Any approved medical centre, university or research institute

Country of Study: Australia

No. of awards offered: Up to 6

Application Procedure: See guidelines in website.

Closing Date: August 31st

Additional Information: Please see the website for further details www.kidney.org.au/HealthProfessionals/MedicalResearchFunding/ tabid/633/Default.aspx.

\section{For further information contact:}

Email: research@kidney.org.au

Contact: Joanna Stoic, Medical Director's Office

\section{Investigator Driven Research Grants and Scholars}

Subjects: Multiple sclerosis research.

Purpose: To award investigators who have applied to the NHMRC for funding but have just missed the cut-off mark.

Eligibility: Open to projects that are ranked as worthy of funding.

Type: Scholarship

Frequency: Annual

No. of awards offered: 1

Contributor: Kidney Health Australia

Kidney Health Australia Seeding and Equipment Grants

Subjects: The functions or diseases of the kidney, urinary tract and related organs, or relevant problems, dialysis, transplantation, organ donation and research.

Purpose: To provide financial support for research projects related to the kidney and urinary tract.

Eligibility: Open to Australian citizens connected with Australian universities or medical centres with requisite research facilities.

Level of Study: Unrestricted

Type: Grant

Value: Up to Australian $\$ 15,000$ per year

Length of Study: Up to 2 years

Frequency: Annual

Study Establishment: Any medical centre, university or research institute

Country of Study: Australia

No. of awards offered: $30-35$

Application Procedure: Applicants must contact the Foundation for details.

Closing Date: June 30th

\section{KIDNEY RESEARCH UK}

Nene Hall, Lynch Wood Park, Peterborough, Cambridgeshire, PE2 6FZ, England

Tel: (44) 03003031100

Email: grants@kidneyresearchuk.org

Website: www.kidneyresearchuk.org

Contact: Mrs Elaine Davies, Director of Research Operations

Kidney Research UK aims to advance and promote research into kidney and renal disease. These may include epidemiological, clinical or biological approaches to relevant problems. All research must be carried out in the United Kingdom.

\section{Allied Health Professional Fellowship (clinical)}

Subjects: Renal medicine.

Purpose: To enable nurses and allied health professionals to undertake a renal research study and obtain a higher degree (Masters, DPhil or PhD).

Eligibility: Open to nurses and allied health professionals to undertake a renal research study with the object of obtaining a higher degree (Masters, DPhil or PhD). Work and employment must be in the UK.

Level of Study: Doctorate, Postdoctorate, Postgraduate

Value: The salary will be based on the appropriate NHS or university scale, and an allowance for consumables and higher degree fees is included

Length of Study: 3 years at full time or 5 years at part time
Frequency: Annual

No. of awards offered: Likely to be no more than 1

Application Procedure: Applicants must complete an online application.

Closing Date: Late November (check with website)

\section{Kidney Research UK Non-Clinical Senior Fellowships}

Subjects: Renal medicine and related scientific studies.

Purpose: Supports non-clinical scientists who have conducted independent research in the renal field and wish to build on their history and reputation in this field, deepening their knowledge and experience.

Eligibility: Open to postdoctoral researchers in the biomedical field with evidence of independent research. Applicants may be of any nationality but project work must be carried out in the United Kingdom. Level of Study: Postdoctorate, Professional development, Research Type: Fellowship

Value: The Fellow's salary plus a UK£24,000 allowance per year for consumables, over a maximum term of 5 years

Length of Study: 3-5 years, subject to review in the 3rd year

Frequency: Annual

Study Establishment: Any institution

Country of Study: United Kingdom

No. of awards offered: Varies

Application Procedure: Applicants must complete an online application form.

Closing Date: November 25th (check with website)

Funding: Private

Contributor: Public donations

No. of awards given last year: 0

No. of applicants last year: 0

Additional Information: Please see the website for further details www.kidneyresearchuk.org/research/fellowship-awards-2016.

\section{Kidney Research UK Research Project and Innovation} Grants

Subjects: Renal medicine.

Purpose: To support both basic scientific and clinical research towards improving the understanding of renal disease, its causes, treatment and management.

Eligibility: Open to suitably qualified researchers of any nationality. Work must be carried out in the United Kingdom.

Level of Study: Unrestricted

Type: Project grant

Value: Up to UK£200,000 over 1-3 years for a full research project grant, and up to UK£40,000 over 1-2 years for an innovation grant

Length of Study: $1-3$ years

Frequency: Annual

Study Establishment: Any institution

Country of Study: United Kingdom

No. of awards offered: Varies

Application Procedure: Applicants must complete an online application form.

Closing Date: Early March (check with website)

Funding: Private

Contributor: Public donations

No. of awards given last year: 10

No. of applicants last year: 77

Additional Information: Please see the website for more details www.kidneyresearchuk.org/research/research-project-and-innovation-awards-2016.

\section{Kidney Research UK Training Fellowships/Career Development Fellowships}

Subjects: Renal medicine and related scientific studies.

Purpose: To enable medical or scientific graduates and undertake specialized training in renal research.

Eligibility: Open to medical candidates of immediate postregistration to registrar level and to science candidates with a PhD or DPhil and at least 2 years of postdoctoral experience. Project work must be carried out in the United Kingdom.

Level of Study: Postdoctorate, Professional development, Research Type: Fellowship 
Value: The Fellow's salary based on the appropriate NHS or university scale, higher degree fees and a consumables allowance of $£ 15,000$ per year, up to a maximum of 3 years

Length of Study: 1-3 years, subject to annual review

Frequency: Annual

Study Establishment: Any institution

Country of Study: United Kingdom

No. of awards offered: Varies

Application Procedure: Applicants must complete an online application form

Closing Date: November 25th (check with website)

Funding: Private

Contributor: Public donations

No. of awards given last year: 3

No. of applicants last year: 26

Additional Information: Please see the website for more details www.kidneyresearchuk.org/research/grant-types.php.

\section{PhD Studentships}

Subjects: Renal medicine.

Purpose: To enable postgraduates to start a career in renal medicine by completing a course of training including submitting a $\mathrm{PhD}$ thesis. Eligibility: Open to active Kidney Research UK Research Project and Innovation Grant holders. Work must take place in the United Kingdom.

Level of Study: Postgraduate

Type: Studentship

Value: The student's stipend based on the appropriate MRC scale, higher degree fees and a consumables allowance of $£ 2,000$ per year, up to a maximum of 3 years

Length of Study: 3 years, subject to a satisfactory annual report Frequency: Annual

Study Establishment: Any institution

Country of Study: United Kingdom

No. of awards offered: Varies (only offered to current grant holders) Application Procedure: Eligible applicants must complete an online application form.

Closing Date: Check with website

Funding: Private

Contributor: Public donations

No. of awards given last year: 5

No. of applicants last year: 10

Additional Information: Those eligible will have access to the online application. Ineligible applicants will not.

\section{KING'S COLLEGE LONDON}

Strand, London, WC2R 2LS, United Kingdom Tel: (44) 02078365454

Fax: (44) 02078483460

Email: ceu@kcl.ac.uk

Website: www.kcl.ac.uk

King's College is one of the oldest and largest colleges of the University of London with 13,800 undergraduate students and some 5,300 postgraduates in 9 schools of study. It was founded in 1,829 as a university college in the tradition of the Church of England.

\section{Australian Bicentennial Scholarships and Fellowships}

Subjects: Any discipline.

Purpose: To promote scholarship, intellectual links, and mutual awareness and understanding between the UK and Australia.

Eligibility: An applicant for a scholarship must be registered as a postgraduate student at an Australian tertiary institution, and must have at least an upper second class Honours degree.

Level of Study: Postgraduate

Type: Fellowship/Scholarship

Value: Up to UK£4,000 per year

Length of Study: Minimum 3 months

Frequency: Annual

Country of Study: Australia

No. of awards offered: Varies

Application Procedure: The application should include a curriculum vitae, the names of two referees, a statement of the research project (approximately 2 sides of $\mathrm{A} 4$ ) and where it is to be carried out.
Closing Date: April 5th

Additional Information: Applications and references for current year will be accepted by email only between February 15th and April 19th. Please see the website for further details www.kcl.ac.uk/artshums/ ahri/centres/menzies/scholarships/absf/absfa.aspx.

\section{Baillie Gifford Prize Fellowship}

Subjects: All Subjects that fall within the remit of the King's India Institute. Core areas of interest at the King's India Institute include: Politics, Public Policy and Political Economy; Anthropology and Social Change; History; Cultural Production (including the media); Foreign and Security Policy; Science, Technology and Policy in India.

Eligibility: Fellowship is open to applicants of all nationalities. Midcareer professionals are particularly encouraged to apply.

Type: Prize

Value: Total offer is of $£ 30,000$. The Fellowship, worth up to $£ 30,000$, will cover the tuition fees of the successful candidate, in addition to providing a stipend to cover living costs over 1 year for a full-time student (2 years for a part-time student)

Country of Study: United Kingdom

Application Procedure: Applicants should include a one page statement with the application to the MRes Contemporary India describing the academic background and where relevant professional experience also stating how the proposed research will contribute to the field. Applicants for the fellowship should submit their full application.

Closing Date: December 13th

\section{Bridget Clarke Bursary for Early Modern History} Subjects: History.

Purpose: Bridget Clarke Bursary, generously funded by Ms Bridget Clarke, will be offered to the strongest full-time applicant to MA in

Early Modern History.

Eligibility: The bursary will be offered to the strongest full-time applicant to MA in Early Modern History who is not in receipt of any other funding. It is open to all nationalities.

Level of Study: Postgraduate

Type: Bursary

Value: $£ 1,000$

Country of Study: United Kingdom

No. of awards offered: 1

Application Procedure: No application is necessary. All MA applications submitted by July 1 st will be considered.

Closing Date: From October 1st until July 1st

Additional Information: Successful candidates will be notified as soon as possible after July 15 th.

\section{Department of History: Peltz Scholarships}

Subjects: The scholarship is awarded in contemporary British history, history, history of art at King's College London in the UK.

Eligibility: These awards will be available on academic achievement and promise. Candidates must be applying to take one of the Masters programmes (excluding the MA in Science, Technology and Medicine) offered by the Department of History on a full-time basis, and without any other scholarship funding. Applicable subjects Contemporary British History, History, History of Art. Scholarships are open for international students at King's College London in the UK.

Level of Study: Postgraduate

Type: Scholarship

Value: Each scholarship is worth $£ 5,000$

Country of Study: United Kingdom

No. of awards offered: 2

Application Procedure: No additional application is necessary: all MA applications submitted by July 1 st will be considered.

Closing Date: July 1st

Contributor: Mr Daniel Peltz

\section{Department of Social Science, Health and Medicine Bursaries for International Students}

Subjects: Social science, health and medicine.

Eligibility: Open to residents of all countries. All students applying for any of the full-time taught masters programmes within the Department of Social Science, Health \& Medicine beginning in September are eligible for these bursaries, including UK, EU and Overseas/International students. 
Type: Bursary

Value: $£ 2,000$ per award

Frequency: Annual

No. of awards offered: 5

Application Procedure: There is no separate application procedure for the bursaries. All individuals who have submitted a complete application by midnight on the May 29th will be considered for the bursaries automatically. A fully completed application includes a complete online application form, and also all supporting documents including personal statements, transcripts, references and IELTS certificates (where appropriate). All materials must have been submitted via the Postgraduate Admissions Portal by the due time and date.

Contributor: Department of Social Science, Health \& Medicine,

King's College London

Additional Information: The successful candidate will be notified no later than June 19th. Payments will be made in October and January.

\section{Geography Department: Masters Bursaries}

Subjects: Geography.

Purpose: The Geography Department has two bursaries for Home/ EU students and two bursaries for International/Overseas students. Eligibility: It is eligible for students taking on any Master's programmes in the Geography Department at King's College London in the coming academic year.

Type: Bursary

Value: $£ 1,000$ (UK/EU students) or $£ 2,000$ (overseas students)

No. of awards offered: 4

Application Procedure: Students who have applied for admission by May 31st are automatically considered for the bursaries. There is no additional form to complete.

Closing Date: From August 1st until May 31st

Additional Information: Successful candidates will be notified by email once the final decisions have been made.

\section{Jinty Nelson Masters Bursary for Medieval History \\ Subjects: Medieval studies, History.}

Purpose: Jinty Nelson Bursary, generously funded by an anonymous donor, will be offered to the strongest full-time applicant to MA Medieval History.

Eligibility: It is open to all nationalities and offered to the strongest full-time applicant to MA Medieval History who is not in receipt of any other funding.

Level of Study: Postgraduate

Type: Bursary

Value: $£ 1,000$

No. of awards offered: 1

Application Procedure: No application is necessary. All MA

applications submitted by July1st will be considered.

Closing Date: From October 1st until July 1st

Additional Information: Successful candidates will be notified as soon as possible after July 15th.

\section{MA Bursaries for STEM Education}

Subjects: Mathematics education, science education, and computing in education.

Eligibility: Open to residents of all nationalities. Available to any applicants who have been awarded, or are currently studying for, a PGCE at King's College London. Applicants must also be applying to undertake one of the following MA programmes at King's, commencing September: MA Mathematics Education; MA Science Education; MA Computing in Education.

Level of Study: Graduate, Postgraduate

Type: Bursary

Value: The bursaries are worth 50 per cent of fees, and will be paid in the form of fee remission

Frequency: Annual

No. of awards offered: Up to 15

Application Procedure: Applicants should complete the form available below with their details and an outline of why they want to complete their MA. This should be submitted to pgce@kcl.ac.uk. Successful applicants will be contacted by email.

Additional Information: Please visit www.kcl.ac.uk/graduate/ funding/database/index. php?action $=$ view\&id $=571$ for more details.

\section{Mark Woodhouse Bursary for Modern History}

Subjects: History.

Purpose: Mark Woodhouse Bursary, generously funded by Mr Mark Woodhouse, will be offered to the strongest full-time applicant to MA in Modern History.

Eligibility: It is open to all nationalities. The award will be offered on academic achievement and promise. The award will be offered to the strongest full-time applicant to MA in Modern History who is not in receipt of any other funding.

Level of Study: Postgraduate

Type: Bursary

Value: $£ 1,000$

No. of awards offered: 1

Application Procedure: No application is necessary. All MA applications submitted by July 1 st will be considered.

Closing Date: October 1st until July 1st

Additional Information: Successful candidates will be notified as soon as possible after July 15 th.

\section{KNUT AND ALICE WALLENBERG FOUNDATION}

PO Box 16066, SE-103 22 Stockholm, Sweden Website: www.wallenberg.com

The Knut and Alice Wallenberg Foundation is the largest private financier of research in Sweden and also one of Europe's largest. The purpose of the Foundation is to promote scientific research, teaching and education beneficial to the Kingdom of Sweden.

\section{Postdoctoral Scholarship Program at Stanford}

Purpose: The purpose of the program is to bring outstanding young Swedish scientists to Stanford University for 1 to 2 years of postdoctoral study and research.

Eligibility: The applicants should have a doctor's degree from a Swedish University at the time when the postdoc period starts. Scientific merits in relation to age will an important factor at the assessment.

Type: Scholarship

Value: The Stipend amounts to approx. US $\$ 45,000$ annually (the final amount will be set in accordance with the standard rate of each institution). A travel grant of US $\$ 5,000$ per year and an annual allowance for accompanying family members of US $\$ 15,000$ is also provided

Length of Study: Up to 2 years

Application Procedure: The Foundation uses an electronic application system. A complete application should contain the applicant's curriculum vitae and include a list of publications, a brief description of the proposed research programme and a description of the research profile of the intended host and supervisor. A letter of recommendation from the intended host should be sent directly to the Foundation. If the applicant has not received the doctorate exam at the time of the application a letter from the supervising professor should be enclosed where the actual date for the exam is stated. Each applicant should ensure that two separate letters of recommendation with comments on the research programme are submitted directly to the Foundation before the end of the application term. The application shall be written in English.

Closing Date: November 15th

Additional Information: A list of successful applicants will be published on the website late Spring. For detailed information, visit www.wallenberg.com/kaw/wallenberg-foundation-postdoctoralscholarship-program-stanford.

\section{THE KOSCIUSZKO FOUNDATION}

The Kosciuszko Foundation, Inc., 15 East 65th Street, New York, NY, 10065, United States of America Tel: (1) 2127342130 Fax: (1) 2126284552

Email: addy@thekf.org, info@thekf.org Website: www.thekf.org

The Kosciuszko Foundation, founded in 1925, is dedicated to promoting educational and cultural relations between the USA and 
Poland and increasing American awareness of Polish culture and history. In addition to its grants and scholarships, which total US $\$ 1,000,000$ annually, the Foundation presents cultural programmes including lectures, concerts and exhibitions, promotes Polish culture in the USA and nurtures the spirit of multicultural co-operation.

\section{Chopin Piano Competition}

Subjects: Piano performance of Chopin or other composers.

Purpose: To encourage highly talented students of piano to study and play works of Chopin and other Polish composers.

Eligibility: Open to students between the age of 16 and 22 who are citizens of the USA or full-time international students in the USA with a valid visa who wish to pursue a career in piano performance.

Level of Study: Unrestricted

Type: Prize

Value: First prize of US $\$ 5,000$, a second prize of US $\$ 2,500$, and a third prize of US $\$ 1,500$. Scholarships may be awarded in the form of shared prizes

Frequency: Annual

Country of Study: United States of America

No. of awards offered: 3

Application Procedure: Applicants must complete an application

form, available in December via the Kosciuszko Foundation's Cultural Department. Applications should be marked Chopin Piano Competition.

Closing Date: October 3rd

No. of awards given last year: 3

No. of applicants last year: 15

Additional Information: The required repertoire is as follows:

Chopin: one Mazurka of the contestant's choice and two major works; Szymanowski: one Mazurka of the contestant's choice; a major work by Bach, excluding The Well-Tempered Clavier; a complete sonata by Beethoven, Hadyn, Mozart or Schubert; a major 19th-century work (including Debussy, Ravel, Prokofiev and Rachmaninoff but excluding those already mentioned); and a substantial work by an American, Polish or Polish-American composer written after 1950. The competition is held on 3 consecutive days in mid-April.

\section{For further information contact:}

Chopin Piano Competition, Kosciuszko Foundation, 15 East 65th Street, New York, NY, 10065, United States of America

Tel: (1) 2127342130

Fax: (1) 2126284552

\section{Dr Marie E Zakrzewski Medical Scholarship}

Subjects: Studies towards an MD degree.

Purpose: To fund a young American woman of Polish ancestry for the first, second or third year of medical studies at an accredited school of medicine in the USA.

Eligibility: The applicant must be a woman of Polish descent who is a citizen of the USA or a Polish citizen with permanent residency status in the USA, entering the first, second or third year of studies towards an $\mathrm{MD}$ degree with a minimum grade point average of 3.0.

Level of Study: MD

Type: Scholarship

Value: US $\$ 3,500$

Length of Study: 1 academic year

Frequency: Annual

Study Establishment: An accredited school of medicine in the USA Country of Study: United States of America

No. of awards offered: 1

Application Procedure: Applicants must submit a tuition scholarship application form, a US $\$ 35$ non-refundable application fee and supporting materials to the Kosciuszko Foundation. Emailed and faxed materials will not be considered.

Closing Date: January 29th - Application, Financial Information Form, Statement of Purpose, Passport-size photo and \$35 nonrefundable application fee. January 20th - Transcripts, Letters of Recommendation, Outline of Polish Ancestry and Supporting Documents and optional items such as curriculum vitae/resume. May 31st - copy of your Letter to Acceptance to Medical School Funding: Foundation, private

Contributor: Kosciuszko Foundation

No. of awards given last year: 1
Additional Information: First preference is given to residents of the state of Massachusetts. Qualified residents of New England are considered if no first-preference candidates apply. Scholarship decisions in late May.

\section{For further information contact:}

Grants Department, Kosciuszko Foundation, Inc., 15 East 65th Street, New York, NY, 10065

Tel: 2127342130 ext. 210

\section{Graduate Study and Research in Poland Scholarship \\ Subjects: All subjects.}

Purpose: To enable American students to pursue a course of graduate or postgraduate study and research in Poland.

Eligibility: Graduate level students and university faculty members who are US citizens. Polish citizens are not eligible.

Level of Study: Doctorate, Graduate, Postgraduate, Research

Type: Grant

Value: 1,350 zloty per month for housing and living expenses provided by the Polish Ministry. Additional funding of $\$ 300$ per month of approved study/research is awarded by the Kosciuszko Foundation Length of Study: Up to 9 months, October to June

Frequency: Annual

Study Establishment: Accredited institutions falling under the jurisdiction of the Polish Ministry of Education and Science

Country of Study: Poland

No. of awards offered: Varies

Application Procedure: Applicants must submit an application form and supporting materials with a $\$ 50$ non-refundable application fee. Applications are available in the Autumn, by mail or from the website www.thekf.org.

Closing Date: January 15th

Funding: Foundation, government, private

Contributor: The Kosciuszko Foundation and the Polish Ministry of National Education

No. of awards given last year: 1

No. of applicants last year: 5

Additional Information: Applicant must submit a research proposal and invitation from the host institution. Invitation must specify period of research/study and the conditions that will apply to the candidate's term in Poland (access to archives, libraries, housing etc.). Scholarship decisions in June or July.

For further information contact:

Exchange Programs to Poland, Kosciuszko Foundation, 15 East 65th Street, New York, NY, 10065, United States of America

Tel: (1) 2127342130 ext. 210

\section{Marcella Sembrich Memorial Voice Scholarship Competition}

Subjects: Polish music.

Purpose: To encourage young singers to study the repertoire of

Polish composers and to honour the great Polish soprano, Marcella Sembrich.

Eligibility: Open to all singers preparing for professional careers who are citizens of the USA or international full-time students with valid student visas, at least 18 years of age and born after May 13th, 1969. Level of Study: Unrestricted

Type: Scholarship

Value: $\$ 3,000$ (1st prize); $\$ 1,500$ (2nd prize); $\$ 500$ (3rd prize)

Frequency: Every 2 years

Country of Study: Any country

No. of awards offered: 3

Application Procedure: Applicants must submit a competition application form and a non-refundable fee of US $\$ 35$ with supporting documents, suggested programme and two copies of an audio cassette recording of approx. $10 \mathrm{~min}$.

Closing Date: March 17th

Funding: Foundation, individuals, private

\section{The Metchie J E Budka Award of the Kosciuszko Foundation}

Subjects: Polish literature from the 14th century to 1939, and Polish history, the state, the nation and the people from 962 to 1956. 
Purpose: To reward outstanding scholarly work in Polish literature, Polish history and Polish-American relations.

Eligibility: Applicants must be graduate students in colleges and universities of USA and Doctoral degree recipients from these institutions who apply during, or at the close of, the first 3 years of their postdoctoral scholarly careers.

Level of Study: Doctorate, Graduate

Type: Award

Value: US $\$ 3,000$

Study Establishment: Colleges and universities of USA

Country of Study: United States of America

No. of awards offered: Varies

Application Procedure: Applicants must send four copies of each complete submission together with a cover letter.

Closing Date: July 20th

Funding: Private

Additional Information: Materials to be submitted: two original articles, or comparable material written in English in a form appropriate for publication or published in a refereed scholarly journal, or annotated translations into English from the original Polish of one or more significant works, which fall within the designated guidelines.

For further information contact:

The Metchie J. E. Budka Award, The Kosciuszko Foundation, 15 East 65th Street, New York, NY, 10065-6595

Tel: 2127342130

Fax: 2126284552

The Polish-American Club of North Jersey Scholarships Subjects: All subjects

Purpose: To financially aid full-time undergraduate and graduate students in the USA. Applicant must be a member of the Polish American Club of North Jersey.

Eligibility: Applicants must be citizens of the USA or permanent residents of Polish descent, active members of the Polish-American Club of North Jersey, have a minimum grade point average of 3.0 and be children or grandchildren of Polish-American Club of North Jersey members.

Level of Study: Graduate, undergraduate

Type: Scholarship

Value: US $\$ 500-2,000$

Length of Study: 1 academic year (September to May)

Frequency: Annual

Study Establishment: An accredited 4-year institution in the US

Country of Study: United States of America

No. of awards offered: Varies

Application Procedure: Applicants must complete a KF tuition scholarship application form, available on the website from October to the end of December. A US $\$ 35$ non-refundable application fee is required. Supporting materials and proof of Polish descent are required. Emailed and faxed materials will not be considered.

Closing Date: January 29th

Funding: Foundation

Contributor: Polish American Club of North Jersey

No. of awards given last year: 5

No. of applicants last year: 6

Additional Information: Only one member per immediate family may receive a Polish-American Club of North Jersey Scholarship during any given academic year. Scholarship decisions in late May.

For further information contact:

Grants Department, Kosciuszko Foundation, Inc., 15 East 65th Street, New York, NY, 10065

Tel: 2127342130 ext. 210

Email: Addy@thekf.org

\section{Tuition Scholarship Program}

Subjects: Polish-American related issues and activities. All subjects are supported. American citizens (non-heritage) are supported when majoring in Polish subject areas.

Purpose: To provide financial aid to U.S. students of Polish descent and to permanent residents (Polish citizen) for graduate-level studies. Eligibility: Open to citizens of the USA of Polish descent and Polish citizens who are legal permanent residents of the USA, who are pursuing graduate studies in any field at a U.S. Institute of Higher Education, or citizens of the USA (non-heritage) who are pursuing a major in Polish studies at the graduate level. All entrants must have a grade point average of 3.0 .

Level of Study: Graduate, Doctorate

Type: Scholarship

Value: US $\$ 1,000-7,000$

Length of Study: 1 academic year, renewable for a further academic year

Frequency: Annual

Study Establishment: Accredited institutions in the USA and certain programmes in Poland

Country of Study: United States of America

No. of awards offered: Varies

Application Procedure: Applications available on-line from October through December. Applicants must submit application-supporting materials and a US $\$ 35$ non-refundable application fee by the deadline date.

Closing Date: January 29th - Application, Financial Information Form, Statement of Purpose, Passport sized Photo, and $\$ 35$ non-refundable application fee; January 20th - Transcripts, Letters of Recommendation, Outline of Polish Ancestry and Supporting Documents and optional items such as curriculum vitae/resume; May 31st - copy of your Letter of Admission to Graduate School Funding: Foundation

Contributor: Kosciuszko Foundation

No. of awards given last year: 30

No. of applicants last year: 84

Additional Information: Information and guidelines are available all year round. A student can receive funding through the Tuition Scholarship programme no more than twice. Only one member per immediate family may receive a Tuition Scholarship during a given academic year. Scholarship decisions in late May.

For further information contact:

Tuition Scholarships, Kosciuszko Foundation, Inc., 15 East 65th Street, New York, NY, 10065

Tel: 2127342130 ext. 210

\section{Year Abroad Program}

Subjects: Polish language, history, literature and culture.

Purpose: To support the study of Polish language, history and culture at the undergraduate and graduate levels by US citizens.

Eligibility: Open to citizens of the USA who are undergraduate- or graduate-level students and who have a minimum GPA of 3.0.

Level of Study: Graduate, Postgraduate

Type: Scholarship

Value: 1,350 Polish Zloty per month for housing and living expenses from the Polish Ministry of Education and Science. Additional funding of $\$ 900$ per semester is awarded by the Kosciuszko Foundation

Length of Study: 1-2 Semesters

Frequency: Annual

Study Establishment: Jagiellonian University Center for Polish Language and Culture, Krakow Poland

Country of Study: Poland

No. of awards offered: Varies

Application Procedure: Applicants must complete an application

form, submit supporting materials and a $\$ 50$ non-refundable application fee by the deadline date. Application forms are available on-line from October through December.

Closing Date: Scholarship application and essay are due on January 7th; supporting materials are due on January 15th

Funding: Foundation, government

Contributor: Polish Ministry of Education and Science and the

Kosciuszko Foundation

No. of awards given last year: 5

No. of applicants last year: 13

Additional Information: Students may apply for one semester or a full academic year. Notification in June or July.

For further information contact:

Exchange Program to Poland, Kosciuszko Foundation, Inc., 15 East 65th St., New York, NY, 10065

Tel: 2127342130 ext. 210 


\section{THE KRELL INSTITUTE}

Krell Institute, 1609 Golden Aspen Drive, Suite 101, Ames, IA, 50010, United States of America

Tel: (1) 5159563696

Fax: (1) 5159563699

Email: csgf@krellinst.org

Website: www.krellinst.org/csgf

Krell Institute was founded in 1997. The goal of the Krell Institute has been to provide superior technical resources, knowledge and experience in managing technology-based education and information programmes. They have done just that, developing outstanding fellowship programmes, educational outreach programmes and information management and exchange programmes.

\section{Department of Energy Computational Science Graduate Fellowship Program}

Subjects: Computational science.

Purpose: Provides outstanding benefits and opportunities to students pursuing doctoral degrees in fields of study that use high performance computing to solve complex science and engineering problems. Eligibility: Open to citizens and permanent residents of the US, undergraduate seniors, first and second year graduate student in a PhD programme.

Level of Study: Graduate, Research

Type: Fellowship

Value: $\$ 36,000$ yearly stipend. Payment of full tuition and required fees. Yearly conferences. $\$ 5,000$ academic allowance in the first fellowship year. $\$ 1,000$ academic allowance each renewed year. 12-week research practicum. Renewable up to 4 years

Frequency: Annual

Country of Study: United States of America

No. of awards offered: Varies

Application Procedure: Apply online through the website www. krellinst.org/csgf/application.

Closing Date: January 8th

Funding: Government

Contributor: Department of Energy (Office of Science and National Nuclear Security Administration)

No. of awards given last year: 16

No. of applicants last year: 396

Additional Information: Please see the website for further details www.krellinst.org/csgf/about-doe-csgf.

\section{THE KURT WEILL FOUNDATION FOR MUSIC}

7 East 20th St., New York, NY, 10003, United States of America Tel: (1) 2125055240

Fax: (1) 2123539663

Email: kwfinfo@kwf.org

Website: www.kwf.org

Contact: Ms Elizabeth Blaufox, Assoc. Director of Programs

The Kurt Weill Foundation for Music is a non-profit, private foundation chartered to preserve and perpetuate the legacies of the composer Kurt Weill (1900-1950) and his wife, singer and actress Lotte Lenya (1898-1981). The Foundation awards grants and prizes, sponsors print and online publications, maintains the Weill-Lenya Research Center and administers Weill's copyrights.

\section{Kurt Weill Foundation Grant Program}

Subjects: Awards financial support worldwide to not-for-profit organizations for performances of musical works by Kurt Weill and Marc Blitzstein, to individuals and not-for-profit organizations for scholarly research pertaining to Kurt Weill, Lotte Lenya, and Marc Blitzstein, and to not-for-profit organizations for relevant educational initiatives. Funding categories include: Professional Performance; Media; College/University Performance; Educational Outreach/ Community Engagement (including Kurt Weill Mentors); Kurt Weill Dissertation Fellowship; Publication Assistance; Research and Travel. Purpose: To fund projects that aim to perpetuate the legacies of Kurt Weill, Lotte Lenya, and Marc Blitzstein.

Eligibility: There are no eligibility restrictions.
Level of Study: Unrestricted

Type: Grant

Value: Relative to the size and scope of project

Frequency: Annual

Country of Study: Any country

No. of awards offered: Varies

Application Procedure: Applicants must submit an application form plus other documentation. Guidelines and forms are available at www.kwf.org.

Closing Date: November 1st. Applications for support of major professional productions/festivals/exhibitions, etc., will be evaluated on a case-to-case basis without application deadlines

Funding: Private

\section{Kurt Weill Prize}

Subjects: Encourages distinguished scholarship in the disciplines of Music, Theater, Dance, Literary criticism and history addressing music theater since 1900 (including Opera). Two prizes are awarded biannually: $\$ 5,000$ to the author of the winning book entry; and a prize of $\$ 2,000$ to the author of the winning article entry.

Purpose: To encourage distinguished scholarship in the disciplines of music, theater, dance, literary criticism and history addressing music theater since 1900 (including opera).

Eligibility: Open to nationals of any country.

Level of Study: Unrestricted

Type: Prize

Value: US\$5,000 for books, US\$2,000 for articles

Frequency: Every 2 years

Country of Study: Any country

No. of awards offered: 2

Application Procedure: Applicants must submit five copies of their published work. Works must have been published within the 2 years preceding the award year. Please visit www.kwf.org for additional information.

Closing Date: April 30th, 2017

Funding: Private

\section{KUWAIT FOUNDATION FOR THE ADVANCEMENT OF SCIENCE (KFAS)}

\author{
Ahmad Al Jaber St. - Sharq - State of Kuwait, PO Box 25263, \\ Safat, 13113, Kuwait \\ Tel: (965) 22278100 \\ Fax: (965) 22270421 \\ Email: Publicr@kfas.org.kw \\ Website: www.kfas.org
}

The Kuwait Foundation for the Advancement of Science (KFAS) aims to support efforts for modernization and scientific development within Kuwait by sponsoring basic and applied research, awarding grants to support and encourage research and awarding grants, prizes and recognition to enhance intellectual development. The KFAS also grants scholarships and fellowships for academic or training purposes, holds symposia and scientific conferences and encourages, supports and develops research projects and scientific programmes.

\section{Islamic Organization for Medical Sciences Prize}

Subjects: Medical practice and Islamic Medical Heritage.

Purpose: To support and promote scientific research in the field of Islamic medical sciences.

Eligibility: Applicant must be a citizen of Arab country.

Level of Study: Unrestricted

Type: Prize

Value: Kuwaiti Dinars 6,000, a KFAS shield and certificate of recognition

Frequency: Every 2 years

No. of awards offered: 2

Application Procedure: Nominations must be proposed by universities, scientific institutes, international organizations, individuals, past recipients of the prize and academic bodies.

Closing Date: December 31st

Funding: Private

Contributor: KFAS 


\section{KFAS Kuwait Prize}

Subjects: Basic sciences, applied sciences, literature, arts, social and economic studies and Arabic and Islamic Heritage.

Purpose: To support scientific research and encourage scholars and researchers in Kuwait.

Eligibility: Applicants should have a distinguished and innovative production of great importance in the specified field, published along the past 10 years, for which the nominee was not granted any other prize from any other entity.

Level of Study: Unrestricted

Type: Prize

Value: Kuwaiti Dinar 30,000, which is approx. US $\$ 100,000$, for each prize, in addition to a Gold Medal, a KFAS Shield and a certificate of Recognition that explains the qualifications and importance of the winning work in short. The combined value of the prizes is more than US $\$ 1,000,000$

Length of Study: 10 years

Frequency: Annual

No. of awards offered: 2 (One for Kuwaiti citizens and the other for citizens of Arab countries)

Application Procedure: Applicants must apply themselves or through non-political organizations and may also be recommended by search committees.

Closing Date: Check the website

Funding: Private

Contributor: KFAS

No. of awards given last year: 5

No. of applicants last year: 91

Additional Information: The area of specific specialization varies every year. Please see the website for further details www.kfas.org/ kuwait-prize.html.

\section{Teaching Assistantship for KSP Visiting Faculty Program}

Subjects: Assistantship is awarded in social sciences and the humanities with special emphasis on the study of the Arab World and the Gulf Region.

Purpose: This assistantship is available for teaching at the Paris School in International Affairs of Sciences Po (PSIA).

Eligibility: This opportunity is open to both professors and practitioners, specialists of the Arab World and the Gulf Region. Individuals from all nationalities may apply. Regarding faculty members, applicants must be full-time officers of instruction of professorial rank (e.g. assistant professor, associate professor or university professor). Candidates on sabbatical or on leave will be preferred. Applications from all social sciences and the humanities are welcome.

Type: Assistantship

Value: The KSP Visiting Faculty will continue to receive her/his salary from her/his home institution when applicable. While at Sciences Po, she/he will receive $€ 20,000$ (gross) to help defray the cost of the visit as well as a travel allowance of up to $€ 1,500$, via reimbursement based on original receipts

Country of Study: France
Application Procedure: Applicants should send the required materials in English (cover letter; a short description of the suggested course with a syllabus proposal; a curriculum vitae) to KSP Manager Marie-Zénaïde Jolys by email at mariezenaide.jolys@sciencespo.fr.

Closing Date: January 28th

Additional Information: A teaching position is available for the spring semester (January to May). The final selection will be announced by mid-March.

\section{KWAME NKRUMAH UNIVERSITY OF SCIENCE \& TECHNOLOGY}

Ghana, Africa, South Africa

Tel: (27) 233322060352

Fax: (27) 233322060137

Email: hrd@knust.edu.gh

Website: www.knust.edu.gh

Contact: The Deputy Registrar (Human Resource Development)

Established in 1952, KNUST has a rich history in its evolution into a first class University over the years. Kwame Nkrumah, the African Personality of the Century and pioneer of African independence is the founder of KNUST. KNUST believes in achievement through diligence and commitment.

\section{eSyllabus for Africa Scholarship}

Purpose: The University in collaboration with eSyllabus for Africa is offering scholarships for brilliant but needy students to enable them pursue their University education.

Eligibility: The Scholarship is open to all regular students in the first, second or third year. All brilliant but needy students from the various departments are also eligible to apply. Minimum grade of applicants must be at least Second Class for continuing students and Aggregate 10 for first years. Applicants are to come along with their Acceptance letters, Letters of Recommendation and WASSCE Certificate. Continuing student applicants should include their current University Academic Transcripts, and first years should also add their High School Transcripts. Applicants who are beneficiaries of other scholarships are not eligible to apply for this scholarship.

Type: Scholarship

Value: Scholarship tuition shall be paid directly to the University at the beginning of each academic year. eSyllabus shall assess the need of providing additional assistance for housing, books and other incidentals on a case by case basis

Country of Study: Ghana

Application Procedure: Forms can be downloaded from the University Website. All Application forms should be sent to room 110, Main Administration block. For detailed information, please visit www. knust.edu.gh/announcements/general/application-for-esyllabus-forafrica-scholarship-20132014.

Closing Date: October 31st

Additional Information: Special Scholarship for women in Medicine. 